\title{
ИТОГИ ВЫБОРОВ В ЕВРОПАРЛАМЕНТ В 2019 г. (КОНФЕРЕНЦИЯ В ИМЭМО ИМ. Е.М. ПРИМАКОВА)
}

Аннотация. Краткое содержание межинститутской конференции, состоявшейся в ИМЭМО им. Е.М. Примакова 6 июня 2019 г. Было заслушано 38 докладов и сообщений, посвящённых итогам выборов в Европейский парламент. Рассмотрены как общие проблемы европейского и мирового развития, так и тематика практически всех стран - членов ЕС. Констатировано усиление электоральных позиций партий наџионалистического, популистского и либерального толка, а также экологистов, ослабление влияния христианских демократов, соииал-демократов и консерваторов. Определены ближайшие перспективы работы Европейского парламента и других органов власти ЕС.

Ключевые слова: Евросоюз, Европейский парламент, политические партии, евроскептики, популистьл.

6 июня 2019 г. в Национальном исследовательском институте мировой экономики и международных отношений имени Е.М. Примакова РАН состоялась научная конференция «Итоги выборов в Европейский парламент 2019 года», организованная совместно с Институтом Европы РАН. В её работе приняли участие эксперты из академических институтов (ИЛА РАН, ИНИОН РАН, ИСИ РАН) и других научно-образовательных и исследовательских центров (МГИМО МИД России, Институт мировых цивилизаций, Ярославский государственный университет им. П.Г. Демидова).

В своём приветственном слове заместитель директора ИМЭМО РАН чл.-корр. РАН И.С. Семененко подчеркнула, что выборы 2019 г. по многим параметрам отличались от предыдущих. Произошло значительное изменение политического ландшафта, которое, однако, в разных странах проявилось по-разному. По-новому зазвучали экологические вопросы, включая климатические изменения и их влияние на приток мигрантов в Европу и качество жизни населения. Заметным явлением стало возрастающее значение тематики идентичности. Те партии и движения, которые сумели её «оседлать», существенно продвинулись.

В выступлении директора ИЕ РАН чл.-корр. РАН Ал.А. Громыко было отмечено, что на выборах прежде всего обратила на себя внимание явка избирателей. В мае 2019 г. политический активизм резко вырос, что в целом для политического процесса явление благоприят-

\footnotetext{
(으르цер Владимир Яковлевич - доктор исторических наук, главный научный сотрудник, руководитель Отдела социальных и политических исследований Института Европы РАН. Адрес: 125009, Россия, Москва, ул. Моховая, д. 11, стр. 3.E-mail: partsist@list.ru;

(댜ашнин Юрий Дмитриевич - кандидат исторических наук, руководитель сектора исследований Европейского союза НИ ИМЭМО им. Е.М. Примакова РАН. Адрес: 117997, Москва, ул. Профсоюзная, д. 23. $\boldsymbol{E}$-mail: ykvashnin @ gmail.ru DOI: http://dx.doi.org/10.15211/vestnikieran32019148155
} 
ное. Однако насколько это смягчит проблему демократического дефицита в Евросоюзе - вопрос открытый. Если Европарламент не сможет приспособиться к новой политической ситуации, то в обществе наступит разочарование, и на следующих выборах в ЕП явка может вновь рухнуть.

Очевидный рост интереса избирателей и специалистов к этим выборам отражает ситуацию определённого возврата к временам острой политической конкуренции и даже к классовой сущности партийно-политической борьбы в Европе, да и в США тоже. Долгое время было общим местом при оценке расстановки партий говорить об уходе в прошлое методики распределения основных политических сил по оси «левые - правые». В то же время насущные вопросы социального и экономического благополучия граждан никуда не делись. «Бунт среднего класса», не говоря уже о радикализации настроений на «окраинах» партийно-политических систем, привели к явному оживлению интереса к политическим идеологиям.

То, что теперь принято называть новым популизмом, - во многом не только и частью даже не столько реакция на перипетии европейской интеграции как таковой, сколько форма возвращения в центр политики вопроса «социального контракта», проблем социального неравенства и деградации государства благосостояния. Можно с высокой долей вероятности предположить, что основной вклад в рост явки на евровыборах внесли представители разочарованной части европейского среднего класса.

Как и прогнозировали многие специалисты, сенсации выборы не принесли - евроскептики всех мастей в чём-то прибавили, в чём-то потеряли, в целом оказавшись в выигрыше за счёт партий истеблишмента, но сильно не дотянув до завышенных показателей, которые им легковесно прочили. В таких крупных странах, как Британия, Франция, Италия, Польша, победили евроскептики. Важно отметить, что евроскептики и новые популисты - это далеко не одно и то же: новые популисты, как правило, евроскептики; а последние совсем не обязательно популисты. И конечно, сам евроскептицизм имеет много граней.

Среди итогов выборов ключевых два: во-первых, народники и социал-демократы (альянс социалистов и демократов) получили меньше половины мандатов, и, во-вторых, сильно прибавили либералы (ALDE) и зелёные. Тем самым закончился длительный период доминирования в европейской политике христианских демократов и близких к ним партий с ситуационной опорой на левоцентристов. Однако суммарно главенство системных и проевропейских партий продолжится. В их лице европейский либеральный истеблишмент может даже стать ещё более напористым и нетерпимым к своим оппонентам, чем это было раньше.

Открывая первую сессию, посвящённую общей конфигурации политических партий в ЕП нового созыва, член дирекции ИМЭМО РАН академик РАН В.Г. Барановский констатировал, что, вопреки мнению ряда экспертов, влияние Европарламента на процессы, происходящие внутри интеграционного объединения, неуклонно растёт. Так, начиная с 2014 г. именно евродепутаты избирают председателя Еврокомиссии, голосуя за одну из кандидатур, предложенных Европейским советом с учётом результатов выборов в ЕП.

Врио директора ИНИОН РАН чл.-корр. РАН А.В. Кузнецов отметил, что Европарламент, несмотря на все существующие в ЕС проблемы, получает всё большую легитимность и поддержку населения. Свидетельство тому - высокая явка. На избирательные участки пришли более 50\% граждан ЕС, и рост по сравнению с 2014 г. составил более 8 п.п. В Дании был зафиксирован рекорд, начиная с 1979 г., в Швеции - с момента вступления в ЕС, а в ФРГ после объединения страны. Рекордная явка отмечена в странах Центральной и Восточной Европы, где интерес к выборам в ЕП традиционно ниже, чем в «старых» членах ЕС.

Б.П. Гуселетов, д.полит.н. (ИЕ РАН), рассмотрел итоги выборов в ЕП с точки зрения 
усиления либо ослабления позиций основных идейно-политических течений в современной Европе. Указав на заметный, более 7\%, рост явки избирателей, он особо выделил поражения двух прежних фаворитов - христианских демократов и социал-демократов. Им теперь будет необходимо найти согласованные позиции с явно усилившимися либералами, а возможно и с «зелёными». Что касается партий евроскептического направления, то увеличение их представительства в ЕП не повлияет на общий проевропейский курс этого главного законодательного органа ЕС.

О.И. Каринцев, к.полит.н. (ИМЦ), полагает, что результаты выборов, вероятно, отразятся на ходе европейских реформ в ближайшие годы, так как правящие партии, такие как Европейская народная партия, Альянс либералов и демократов за Европу и Партия европейских социалистов, всё больше перенимают положения евроскептиков в своих программах, в том числе в сфере миграции, обороны и безопасности, расширения $\mathrm{EC}$, перехода большего количества полномочий на национальный уровень и т.д.

Рост влияния ЕП был отмечен и д.полит.н. М.В. Стрежневой (ИМЭМО РАН), которая, однако, обратила внимание на то, что при более сложном составе Европарламента управлять Евросоюзом станет сложнее. В частности, труднее будет находить решения по таким проблемам, как иммиграция, заключение торговых соглашений с США, продление или отмена антироссийских рестриктивных мер и борьба с изменением климата. В то же время европейский политический процесс теперь откроется для большего числа участников с широким разбросом во мнениях, что должно вылиться в более гибкую систему непостоянных, подвижных коалиций по отдельным вопросам.

Одним из главных итогов выборов стало усиление (хотя и не такое значимое, как прогнозировалось) националистического крыла. Вместе с тем, как пояснила д.э.н. М.В. Клинова (ИМЭМО РАН), не все националисты являются евроскептиками и выступают за выход из ЕС. Многие из них борются за корректировку вектора развития евроинтеграции и роли наднациональных органов власти. В числе проблем, которые выделяют националистические партии, утрата части национального суверенитета в связи с интеграцией, усиление евробюрократии в Брюсселе, перемещение производств в развивающиеся страны, дефицит безопасности в связи с массовым притоком мигрантов, размывание национальной идентичности, угроза исламизации. Без корректировки юридических правил в ЕС с учётом новых реалий создаётся почва для укрепления позиций правых националистов внутри европейских стран и в Европарламенте.

А.К. Камкин, к.филос.н. (ИЕ РАН), полагает, что евроскептики ещё не сказали своего последнего слова в политической жизни Европы. Их основная проблема - отсутствие объединяющего начала и договорённости по страновым и глобальным проблемам.

А.А. Синдеев, д.и.н. (ИЕ РАН), рассматривает основные позиции М. Вебера, длительное время остававшегося главным кандидатом на пост председателя Европейской комиссии. Вебер выдвинул семь проектов реформирования ЕС: европейская идентичность, унификация социально-экономического пространства, система европейской безопасности, обновление европейской демократии, новая ответственность элит, солидарность с европейским окружением, завершение европейской интеграции. М. Вебер полагал, что решить эти задачи можно лишь путём обеспечения взаимодействия между разными уровнями европейского власти, прежде всего Европейского парламента, Европейского совета и Европейской комиссии.

Руководитель Центра по изучению проблем религии и общества ИЕ РАН Р.Н. Лункин, д.полит.н. (ИЕ РАН), в докладе «Религия и выборы в Европарламент: борьба за европейскую идентичность» отметил многозначность религиозного фактора в ходе предвыборной борьбы

Научно-аналитический вестник ИЕ РАН, 2019, №3 
за кресла депутатов ЕП. Вера является элементом идентичности у части представителей партий «политической альтернативы». В глазах церковных лидеров стран Евросоюза христианство - это фундамент общеевропейского единства. Однако защищая единую Европу от националистов, мигрантофобии, ксенофобии в целом, руководство католических и протестантских церквей в разных странах часто выступает с более либеральных позиций, чем их собственная паства. В предвыборных заявлениях межцерковных объединений Евросоюза, обращённых к избирателям, содержится призыв пойти и проголосовать, сознавая опасность «популизма». Таким образом, не только в европейском обществе, но и в его христианском сегменте растёт разделение на либералов и традиционалистов, а лидеры церквей (в особенности это видно на примере Католической церкви) этот раскол углубляют.

В.Я. Швейцер, д.и.н. (ИЕ РАН), модератор второй сессии «Результаты выборов в ЕП в ведущих странах ЕС», отметил повышение электорального интереса к данному событию в таких приоритетных государствах Евросоюза, как Германия, Франция, Италия и Испания. По его мнению, это связано не только с ощущением гражданами этих стран особой ответственности за судьбу Европы, но и с повышением в них в последние годы градуса внутриполитической борьбы. Происходят важные подвижки в высших эшелонах власти, появляются новые лидеры, всё увереннее заявляют о себе вчерашние аутсайдеры европейской политики. Именно в этих государствах постепенно складывается консенсус относительно явно антиевропейского курса Д. Трампа. Параллельно с этим намечаются некоторые подвижки в более реалистичном, чем прежде, подходе к роли России в современном мире.

Значительный интерес у участников конференции вызвали результаты выборов во Франции. Анализируя внутриполитические последствия «европейских выборов» в этой стране, к.э.н. А.К. Кудрявцев (ИМЭМО РАН) пришёл к выводу, что относительный успех партии Э. Макрона сохранил благоприятные политические условия для новых преобразований. Однако властям придётся продолжить болезненные реформы в обстановке жёстких социальноэкономических ограничений. В связи с этим они как никогда нуждаются в достижении и предъявлении общественному мнению положительных результатов своей по-литики. И хотя в политическом плане Макрон в очередной раз выиграл, в плане экономическом он остаётся таким же заложником состояния мировой экономики, какими были его пред-шественники Н. Саркози, и Ф. Олланд.

Руководитель центра французских исследований ИЕ РАН д.и.н. Ю.И. Рубинский полагает, что основная интрига выборов заключалась в противостоянии партии Э. Макрона и «Национального объединения» М. Ле Пен. Оба блока завершили выборы с практически одинаковыми результатами, что удовлетворило их лидеров. Э. Макрон снял все проблемы вокруг сохранения себя во главе властной пирамиды, а М. Ле Пен осталась лидером достаточно сильной оппозиции.

Е.А. Нарочницкая, к.и.н. (ИЕ РАН), считает, что Э. Макрон и его партия добились серьёзного успеха, ибо его главная задача - зачистить политическое поле от конкурентов - оказалась выполненный. Ни республиканцы, ни социалисты, ни крайне левые Ж.-Л. Меланшона не смогли организовать поддержку со стороны своего электората.

Г.Н. Канинская, д.и.н. (ЯрГУ им. Демидова), проанализировала успехи партии «Зелёных», считая, что именно экологисты сегодня являются главной силой левой оппозиции.

С.М. Фёдоров, к.полит.н. (ИЕ РАН), констатировал глубокий кризис партии республиканцев, которой в обозримом будущем вряд ли удастся стать новым успешным издание неоголлизма.

Е.П. Тимошенкова, к.и.н. (ИЕ РАН), затронула тему России как фактора влияния на со- 
временную европейскую жизнь. В Германии у таких партий, как «Альтернативы» и «Левые» одним из ключевых моментов их программ является отмена санкций и нормализация отношений с Россией.

В Германии, как отметил к.полит.н. Ф.А. Басов (ИМЭМО РАН), результаты выборов оказались довольно предсказуемыми. Главные тренды - снижение поддержки социал-демократов и примерно такой же рост у партии «Зелёных», которые вместе со своими идеологическими союзниками - «Партией» (Die Partie), «Партией пиратов Германии» и «Экологической демократической партией» - получили 26 мест в Европарламент. Для сравнения, блок ХДС/ ХСС провёл 29 депутатов. Фактически за последние 10 лет в Германии сложилась полуторопартийная система с доминирующей ХДС/ХСС и множеством других партий, значение каждой из которых подвержено серьёзным колебаниям - как на федеральном, так и на земельном уровне. В перспективе вероятно появление новых неожиданных коалиций с всё большим числом участников.

Руководитель центра британских исследований ИЕ РАН к.филос.н. Е.В. Ананьева увязала избирательную кампанию в Великобритании и её итоги на выборах в ЕП с темой брекзита. В результате абсолютным победителем выборов стал «Брекзит» Н. Фараджа, а обе ведущие партии страны - консерваторы и лейбористы - показали самые низкие результаты за почти вековой период выборов в Великобритании. Усилили свои позиции в ЕП партии либеральных демократов и зелёных. Однако предстоящий, в пределах до 31 октября 2019 г., брекзит сделает результаты в ЕП для Великобритании фиктивными, ибо руководство ЕС уже выработало форму замещения британских мест в ЕП представителями других членов этой организации.

Великобритания была вынуждена принять участие в выборах в ЕП, поскольку ей не удалось выйти из Евросоюза в законодательно закреплённый срок (29 марта 2019 г.). По мнению к.и.н. Т.Н. Андреевой (ИМЭМО РАН), нежелание премьер-министра Т. Мэй идти по пути «жёсткого брекзита» и начало переговоров с лейбористами о путях выхода из создавшейся ситуации вызвали массовый отток членов и электората из Консервативной и Лейбористской партий. Этим в полной мере сумели воспользоваться наиболее последовательные сторонники выхода Великобритании из ЕС.

В Италии, заметила к.э.н. А.В. Авилова (ИМЭМО РАН), выборы в ЕП рассматривались прежде всего, как проверка соотношения сил в правительстве «Лиги» - «Движения 5 звезд» (ДП53). Результаты свидетельствуют о победе первой и поражении последней: именно «Лига» во главе с М. Сальвини закрепилась в роли ведущей политической силы. Лидеры обеих партий заявляют, что это не отразится на их сотрудничестве. Сальвини «не будет сводить счёты», Ди Майо (глава ДПЗ) намерен «учиться на ошибках». Однако новое соотношение сил даёт Сальвини возможность усилить давление на партнёра в сфере экономической политики. Для Ди Майо возникла угроза досрочных выборов в национальный парламент, чреватых потерей власти.

Е.А. Алексеенкова, к.полит.н. (ИЕ РАН), считает, что главным итогом европейских выборов для Италии стала легитимация правительства, евроскептиков «Лиги» и «Движения 5 звёзд». Однако налицо и существенные подвижки в электоральной диспропорции участников коалиции. Важным показателем выборов стало относительное усиление европарламентских позиций христианских демократов, которые не отказались от возвращения в той или иной комбинации во властные структуры итальянской политики.

В Испании прошедшие 26 мая выборы, именуемые в СМИ «супервоскресеньем», обозначили различные результаты для левоцентристской Испанской социалистической рабочей партии (ИСРП). С одной стороны, ИСРП, как отметил К.А. Никулин (ИМЭМО РАН), в усло- 
виях перманентного кризиса стала наиболее популярной партией на всех уровнях политической системы. Более того, она заняла лидирующие позиции не только в Испании, но и внутри социал-демократического блока ЕС. Неизбежность перебалансировки сил в традиционных для ЕП коалициях в перспективе способна превратить испанских социалистов во флагмана борьбы с растущим евроскептицизмом и крайне правыми популистскими настроениями. Тем не менее, прочность позиций ИСРП вызывает определённые сомнения, о чём свидетельствуют вероятные сложности с созданием коалиций - как в Европарламенте, так и внутри страны.

В третьей сессии - модератор, ведущий научный сотрудник ИМЭМО РАН, д.э.н. М.В. Клинова, - внимание было сфокусировано на политических последствиях выборов в ЕП в малых странах Евросоюза.

Наиболее стабильными остаются электоральные предпочтения в странах Северной Европы. В своем выступлении к.э.н. А.М. Волков (ИМЭМО РАН) обратил внимание на то, что лишь в одной из них - Дании - результаты «евровыборов» показали существенное изменение политического ландшафта, проявившееся в победе либеральной партии «Венстре» и сокрушительном поражении праворадикальной «Датской народной партии». В Швеции, как и в 2014 г., первое место заняли социал-демократы, а в Финляндии - «Национальная коалиционная партия», представляющая правый центр.

Н.С. Плевако, к.и.н. (ИЕ РАН), обратила внимание на особенности восприятия скандинавским электоратом националистических партий Швеции, Дании и Финляндии. В первой из этих стран - Швеции - партия «шведских демократов» подтвердила на выборах в ЕП свои претензии на ведущую роль в политике этих стран. Напротив, в Дании националисты электорально ослабли, ибо многие их националистических позиции перехвачены правой частью либералов. В Финляндии раскол «Истинных финнов» не даёт им шансов закрепиться в структурах политической власти.

П.В. Осколков (ИЕ РАН) остановился в своём докладе на результатах двух региональных националистических партий Бельгии - «Новый фламандский альянс» и «Фламандский интерес». Если первая несколько ослабила свои позиции в ЕП, то вторая, наоборот, укрепила своё положение. Отчасти это связано с тем, что НФА уже нёс на себе груз правительственной ответственности, а вторая была достаточно активна как оппозиционная сила. Обе партии являются евроскептиками, сочетая эти позиции с давлением на центральную власть Бельгии по вопросам дальнейшей федерализации страны.

В.С. Грибовский (ИЕ РАН) обратил внимание на результаты выборов в Австрии. По его мнению, они свидетельствуют об однозначном успехе С. Курца и его Австрийской народной партии. Во многом этот успех был достигнут за счёт ослабления как его прежнего коалиционного партнёра (Австрийской партии свободы), так и невнятной позиции социал-демократов.

В.О. Охошин, к.и.н. (ИЕ РАН), констатировал сохранение ведущих позиций местных либералов и консерваторов в политической жизни Ирландии. Партии левых и правых флангов проиграли потому, что они не нашли адекватного ответа на сложную ситуацию вокруг брекзита.

В Нидерландах победителем стала «Партия труда», входящая в «Прогрессивный альянс социалистов и демократов». По мнению к.э.н. А.А. Невской (ИМЭМО РАН), это во многом было связано с личным фактором. Лидер партии Ф. Тиммерманс - первый заместитель председателя Еврокомиссии по вопросам устойчивого развития представлялся возможным преемником Ж.-К. Юнкера на посту председателя Еврокомиссии, автором стратегии «циркулярной экономики» ЕС и весьма популярным в стране политиком. В числе аутсайдеров оказались «Партия свободы», известная антимигрантскими высказываниями своего лидера Г. Вильдер- 
са, и левая «Социалистическая партия». Обе не получили ни одного места в ЕП.

В Греции предпочтения избирателей качнулись вправо. Наилучшие результаты показала консервативная «Новая демократия». Возглавлявшая с 2015 г. правительство левая СИРИ3А, хотя и сумела сохранить прежние шесть мест в ЕП, по доле поданных за неё голосов отстала от консерваторов почти на 10\%. После оглашения результатов премьер-министр А. Ципрас был вынужден объявить досрочные выборы в национальный парламент. Среди причин поражения левых к.и.н. Ю.Д. Квашнин (ИМЭМО РАН) назвал разочарование избирателей их экономической политикой, а также репутационными проблемами партии. Изначально позиционировавшая себя в качестве альтернативы старому политическому истеблишменту, придя к власти, СИРИЗА «впитала в себя» все его пороки (коррупция, клиентелизм, фаворитизм и пр.).

В заключительной сессии, модератором которой выступил заведующий Сектором исследований Европейского союза ИМЭМО РАН, к.и.н. Ю.Д. Квашнин, были подведены итоги выборов в постсоциалистических странах.

И.С. Яжборовская, д.и.н., профессор (ИС РАН), отмечает, что в Польше основными соперниками на европейских выборах была правящая ПиС и объединённая европейская коалиция. Последняя сложилась из практически всех ранее бывших во власти политических партий Польши. В конечном итоге, ПиС выиграла выборы за счёт голосов провинциального электората, чутко уловившего националистические позиции ПиС. Однако и оппозиционеры набрали достаточное количество голосов, чтобы положительно оценить свои перспективы на предстоящих в октября 2019 г. очередных парламентских выборах.

М.В. Ведерников, к.и.н. (ИЕ РАН) проанализировал результаты выборов в ЕП в странах Вишеградской группы. По мнению докладчика, их можно разделить на две группы. Если в Чехии и Словакии прежние лидеры партийного дискурса ЧСД и СМЕР утратили прежнюю популярность, но во второй группе и польские ПиС, и венгерский ФИДЕС подтвердили своё лидирующее положение. Во многом это было связно с их активной критической позицией с адрес руководствам ЕС, прежде всего по теме иммиграции.

П.Е. Кандель, к.и.н. (ИЕ РАН), раскрыл в своём выступлении особенности партийной диспозиции в странах Юго-Восточной Европы. Фаворитом выборов стали партии, входящие в общеевропейский блок ЕНП. Социалисты, наоборот, ослабили своё представительство в соответствующем объединении (ПАСД). Практически никак не заявили о себе заметные в общеевропейском контексте «зелёные» и либералы. Политические колебания партий региона можно свести к формуле «евроиждивенчество», когда политиков Юго-Восточной Азии больше волнуют вопросы дотаций от ЕС, чем критика в адрес евроинтеграторов.

В Чехии, как отметила к.э.н. А.С. Четверикова (ИМЭМО РАН), «евровыборы» подтвердили тенденцию к фрагментации политического поля. В Европарламент прошли семь партий (для сравнения, на выборах 2014 г. - всего четыре). Самые успешные из них - популистская ANO 2011, «Гражданская демократическая партия» и «Чешская пиратская партия» - получили соответственно шесть, четыре и три места (из имевшегося 21 места). Согласно опросам, наиболее важными для чешских избирателей были проблемы миграции, защиты национальных интересов, «брекзита», окружающей среды, качества продуктов питания, экономики, реформ в Евросоюзе.

В странах Прибалтики, по мнению к.ю.н. В.А. Оленченко (ИМЭМО РАН), партийная деятельность достаточно статична и не отличается глубокими различиями между электоральными циклами. Идеи евроинтеграции в этих странах циркулируют главным образом в партийно-политической среде, а не среди населения. Успех партий на выборах во многом зависит от персоналий предложенных ими кандидатов. 
Конференция в ИМЭМО РАН продемонстрировала высокий уровень отечественной аналитики по проблемам современной Европы. Все участники, как страноведы, так и знатоки общеевропейских проблем, едины во мнении, что в ближайшие годы европейская полития преподнесёт нам ещё не один сюрприз как в страновом, так и в общеконтинентальном контексте. Тем самым отечественная европеистика будет постоянно востребована на общем фоне других российских зарубежных исследований.

\section{Results of elections to the European Parliament in 2019 (The Conference in Primakov Institute of World Economy and International Relations)}

Authors. Schweizer V.Ya., Doctor of Sciences (History), Head of the Department of Social and Political Studies of the IE RAS. Address: 11-3, Mokhovaya str., Moscow, Russia, 125009. Email: partsist@list.ru; Kvashnin Yu.D., Candidate of Sciences (Economy), Head of the Research Sector for the EU in the IMEMO RAN. Address: 23, Profsoyuznaya str., Moscow, Russia, 117997. E-mail: ykvashnin@gmail.ru.

Abstract. The article summarizes the results of an inter-institutional conference, held at the Primakov Institute of World Economy and International Relations on June 6, 2019. There were heard 38 reports on the recent European Parliament elections. Both general problems of European and global development, as well as issues of almost all EU member states were considered. The strengthening of the electoral positions of nationalist, populist and liberal parties, as well as environmentalists, and the weakening of the influence of Christian democrats, social democrats and conservatives were mentioned. The immediate prospects for the work of the European Parliament and other EU institutions were identified.

Keywords: European Union, European Parliament, political parties, Euro-skeptics, populists.

DOI: http://dx.doi.org/10.15211/vestnikieran32019148155 